\title{
Time Variant Adjustment for The Solution of Control Point Unstability in Deformation Analysis of Borobudur Vertical Deformation Monitoring Network
}

\author{
Dwi Lestari ${ }^{1}$, Yulaikhah ${ }^{1}$, Rizki Iman Sari ${ }^{2}$ \\ 1 Departemen Teknik Geodesi, Universitas Gadjah Mada, INDONESIA \\ 2 Alumni Program Studi Sarjana Teknik Geodesi, Universitas Gadjah Mada, INDONESIA
}

\section{Article History:}

Received 5 September 2018

Received in revised form 21

September 2018

Accepted 23 September 2018

Available online 25 September 2018

\section{Keywords:}

Borobudur temple, least square adjustment, time-variant model, vertical displacement

Corresponding Author:

Dwi Lestari

Email: dwilestari@ugm.ac.id

\begin{abstract}
Monitoring the vertical deformation of the Borobudur temple using Geodetic method is one kind of monitoring work for maintaining the temple as the world's cultural heritage. This work is carried out using leveling method to observe the height of Borobudur monitoring network points periodically. This network was designed using absolute network with one control point. The control point height was assumed to be fix at each epoch in deformation analysis. Multiyear GPS observation at this point, lately indicated that this point was shifted. The control point displacement would cause a systematic error in the adjustment computation method for the analysis of vertical displacement. The correction of control point height due to the vertical shift is needed prior to the adjustment computation using observation model. In addition, there is a time variant adjustment computation method which able to calculate the vertical rate of object point displacement. This study aims to evaluate the use of time variant adjustment for the solution of control point unstability in vertical deformation analysis. This was done by comparing the vertical displacement analysis of the Borobudur's vertical network from the adjustment computation using observation model with the correction of control point height and from time-variant adjustment method. The results showed that vertical displacement magnitude of Borobudur's monitoring points, resulted from the parameter adjustment computation with the correction of control point compared to the timevariant adjustment results was differed in nanometer. Time-variant adjustment computation method gave more accurates result of 1.5 times better than the observation model. Furthermore, time variant method adjustment showed faster processing step which able to estimate the height and the rate of height displacement of network points.
\end{abstract}

(C) Author(s) 2018. This is an open access article under the Creative Commons Attribution-ShareAlike 4.0 International License (CC BY-SA 4.0).

\section{Pendahuluan}

Sebagai salah satu situs warisan budaya dunia, Candi Borobudur senantiasa dilakukan pengawasan serta pemantauan baik secara struktural candi, arkeologi batuan candi, sistem drainase dan lainnya. Pemantauan struktur candi menjadi salah satu hal pokok yang harus dilakukan untuk mengetahui apakah terjadi pergerakan batuan candi yang disebabkan oleh pergerakan tanah di bawah candi sebagai akibat beban dari batuan candi maupun faktor lainnya. Dalam rangka pemeliharaan Candi Borobudur oleh Balai Studi dan Konservasi Candi Borobudur (Balai Konservasi Borobudur/BKB), dilakukan penanaman benchmark (patok) di beberapa lokasi pada badan dan halaman candi yang digunakan sebagai titik-titik pengukuran deformasi atau pergeseran candi baik pada arah horizontal maupun vertikal. Penanaman benchmark dilakukan sesuai dengan perencanaan atau desain jaring.
Desain jaring sipat datar Candi Borobudur tahun 2002 menggunakan kerangka dasar absolut yang meletakan titik ikat di luar area pergeseran. Titik ikat pada kerangka dasar absolut digunakan sebagai titik acuan yang dianggap tidak mengalami pergeseran. Jaring sipat datar tersebut digunakan untuk pengukuran beda tinggi tahun 2002, 2003 dan 2004 oleh tim BKB. Pengukuran jaring menggunakan titik BORE (Gambar 1.1) sebagai titik ikat dalam proses pendefinisian tinggi setiap benchmark yang selanjutnya digunakan untuk analisis deformasi vertikal (Siswoyo, 2002). Analisis deformasi menggunakan jaring absolut sering menggunakan asumsi titik ikat dalam kondisi stabil. Apabila pada kenyataannya titik ikat/titik kontrol tidak betul-betul stabil maka analisis pergerakan yang dihasilkan menjadi kurang tepat.

Analisis pergerakan vertikal Candi Borobudur menggunakan data pengukuran beda tinggi tahun 2002, 2003 dan 2004 telah dilakukan oleh Koesumakristi (2005). 
Penelitian tersebut menggunakan tinggi titik BORE sebagai titik ikat dengan tinggi titik diasumsikan tetap. Pendefinisian tinggi setiap benchmark (titik pantau) menggunakan hitung kuadrat terkecil metode parameter dari data pengukuran beda tinggi tahun 2002, 2003 dan 2004. Penelitian melibatkan 52 titik pantau dan 20 pengamatan. Analisis dilakukan dengan membandingkan vektor pergeseran serta ketelitiannya, antara epoch 2002 dan 2003, 2003 dan 2004, serta 2002 dan 2004. Hasil dari penelitian ditinjau dari aspek geometrik, menunjukkan adanya pergerakan vertikal pada jaring sipat datar Candi Borobudur dengan nilai rerata 2,245 $\mathrm{mm}$ (kenaikan) pada epoch 2002 dan 2003, rerata $-0,476 \mathrm{~mm}$ (penurunan) pada epoch 2003 dan 2004, dan rerata 2,551 mm (kenaikan) pada epoch 2002 dan 2004. Hasil analisis deformasi Candi Borobudur pada studi ini menunjukkan kenaikkan hampir di semua benchmark.

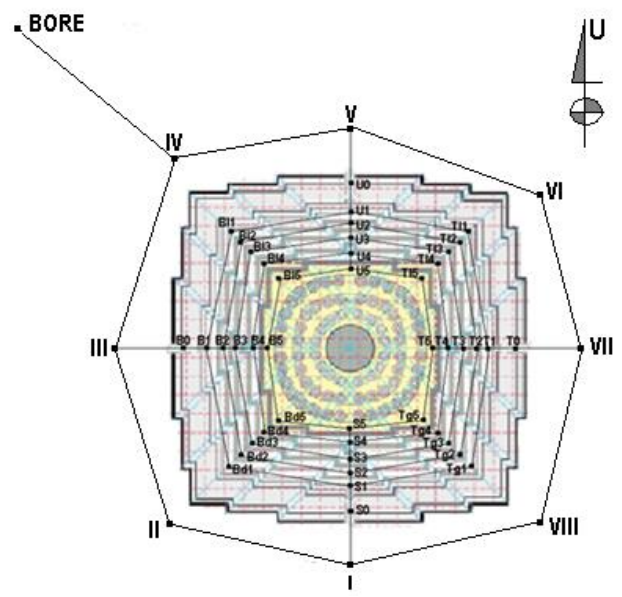

Gambar 1.1 Sketsa jaring sipat datar tahun 2002, 2003 dan 2004 (Siswoyo, 2002)

Studi penurunan tanah akibat konsolidasi di Candi Borobudur telah diakukan oleh Wangsadinata dan Djayaputra (1982), dan Anggraeni (2001). Kedua penelitian ini mengevaluasi stabilitas candi sebagai akibat penurunan yang dilakukan dengan memperhatikan beban yang bekerja, karena adanya penambahan plat beton pada saat pemugaran. Berdasarkan analisis deformasi yang ditinjau dari aspek fisik pada kedua penelitian tersebut diketahui bahwa konsolidasi tanah candi mengakibatkan penurunan. Namun demikian, berdasarkan penurunan jangka panjang serta safety factor yang dihitung dari studi kasus yang dikaji, dapat disimpulkan bahwa Candi Borobudur dalam kondisi aman terhadap pengaruh beban pelat beton.

Penelitian pergerakan vertikal Candi Borobudur berdasarkan data pengamatan GPS dilakukan untuk beberapa epoch pengamatan yaitu tahun 2002, 2003 dan 2012 (Lestari, 2015). Hasil dari penelitian ini adalah terdeteksinya pergerakan titik BORE dengan kecepatan 4,4 $\mathrm{mm} /$ tahun. Hasil ini menegaskan bahwa pergerakan vertikal yang terjadi di Candi Borobudur berupa penurunan, dan fakta bahwa titik kontrol yang dipakai sebagai acuan jaring sipat datar tidak dalam kondisi tetap (stabil), sehingga perlu dilakukan evaluasi terhadap hasil analisis pergerakan vertikal yang diperoleh.
Metode perataan hitung kuadrat terkecil parameter terkendala minimal dapat digunakan dengan baik pada data observasi dan pendefinisian ketinggian benchmark pada satu epoch yang sama. Ketika terdapat perubahan ketinggian titik ikat pada epoch yang berbeda maka perubahan tersebut menyebabkan kesalahan pada model perataan (Han, dkk., 2014). Permasalahan tersebut dapat diatasi dengan melakukan koreksi tinggi titik ikat tiap epoch. Koreksi dilakukan dengan mendefinisikan tinggi titik ikat pada epoch pengukuran beda tinggi. Tinggi titik ikat pada epoch tertentu dapat didenifisikan menggunakan analisis kecepatan pergeseran vertikal (vertical velocity) titik ikat tersebut. Setelah tinggi titik ikat tiap epoch telah terdefinisi, maka metode perataan hitung kuadrat terkecil parameter terkendala minimal dapat digunakan untuk mendefinisikan benchmark pada masing-masing epoch. Selain metode perataan hitung kuadrat terkecil parameter terkendala minimal, terdapat metode lain yang dapat digunakan untuk mengatasi masalah perubahan tinggi titik ikat yakni metode perataan time-variant.

Metode perataan time-variant merupakan metode perataan ketinggian yang menggunakan vector kecepatan pergerakan vertikal sebagai salah satu parameter perhitungannya (Han, dkk., 2014). Penelitian tentang model hitungan perataan time-variant ini bertujuan untuk membentuk model hitungan matematis time-variant pada jaring beda tinggi dengan titik ikat yang mengalami pergerakan vertikal. Pergerakan titik ikat dalam penelitian tersebut diasumsikan berkala setiap tahun atau kecepatan konstan, sehingga faktor pergeseran titik ikat lain seperti gempa bumi tidak diperhitungkan. Parameter yang digunakan dalam model perhitungan time-variant adalah tinggi titik ikat, kecepatan pergerakan vertikal titik ikat, tinggi titik pantau pada epoch tertentu dan kecepatan pergerakan titik pantau pada epoch tertentu. Penelitian tersebut menampilkan simulasi hitungan kuadrat terkecil metode time-variant pada jaring beda tinggi sederhana dan membandingkannya dengan hasil hitungan perataan tanpa koreksi tinggi titik ikat. Hasil simulasi menunjukkan simpangan baku metode time-variant lebih kecil tiga kali lipat dibandingkan simpangan baku hitungan perataan tanpa koreksi tinggi titik ikat.

Berdasarkan latar belakang tersebut, maka pada analisis pergerakan vertikal jaring pemantau deformasi Candi Borobudur perlu dilakukan kajian lagi dengan memperhatikan pergerakan yang ada pada titik ikatnya, yaitu titik BORE. Pada makalah ini kajian dilakukan dengan membandingkan antara besar dan arah vektor pergerakan vertikal beserta ketelitiannya dari hasil hitungan perataan metode paremeter dengan koreksi tinggi titik ikat pada setiap epoch dan dari hasil hitungan perataan metode timevariant pada jaring sipat datar Candi Borobudur. Selanjutnya evaluasi terhadap ketelitian hasil dari masingmasing metode dilakukan untuk mengetahui metode analisis yang tepat.

\section{Data dan Metodologi}

\subsection{Data dan Lokasi}

Data yang digunakan dalam penelitian ini adalah data pengamatan beda tinggi dan jarak pada jaring pantau 
vertikal Candi Borobudur yang diakuisisi pada tahun 2002, 2003 dan 2004 dan data kecepatan pergerakan vertikal titik ikat jaring pantau. Data beda tinggi yang digunakan pada penelitian ini merupakan data yang diakuisisi oleh tim Balai Studi dan Konservasi Borobudur (BKB) pada bulan November tahun 2002 (Siswoyo, dkk., 2002), November tahun 2003 (Siswoyo, dkk., 2003) dan November tahun 2004 (Siswoyo, dkk., 2004). Alat sipat datar yang digunakan oleh BKB adalah tipe otomatik TOPCON AT G2, dilengkapi dengan micrometer, dengan ketelitian $\pm 0,4 \mathrm{~mm}$, dilengkapi dengan rambu invar berukuran $3 \mathrm{~m}$. Adapun alat ukur jarak yang digunakan adalah pita ukur baja dengan panjang $50 \mathrm{~m}$. Pada kajian ini data ketiga tahun tersebut dipilih karena memiliki tingkat ketelitian yang lebih tinggi dibandingkan dengan epoch yang lain dan metode pengukuran yang konsisten untuk tiap epochnya. Data pergerakan titik ikat diperoleh berdasarkan penelitian yang dilakukan oleh Lestari (2015) yang menyebutkan bahwa titik BORE mengalami pergerakan dengan kecepatan $-4,4 \mathrm{~mm} /$ tahun dengan simpangan baku $\pm 0,3 \mathrm{~mm} /$ tahun.

\subsection{Metodologi}

Prinsip kajian yang dilakukan adalah membandingkan hasil analisis pergeseran vertikal menggunakan metode hitung perataan standar menggunakan metode parameter (Caspary, 1987) dengan memberikan koreksi ketinggian titik kontrol pada tiap epoch dengan hasil hitungan tinggi dan laju perubahannya menggunakan metode time variant.

\section{A. Time Variant Adjustment}

Hitung perataan time-variant adalah salah satu metode hitung perataan kuadrat terkecil yang langsung memasukkan koreksi parameter akibat adanya pergerakan pada titik ikat. Prinsip perhitungan metode tersebut sama dengan prinsip hitung kuadrat metode parameter berbobot dimana dalam proses perhitungannya memasukkan bobot pada parameter. Penggunaan tinggi titik ikat yang diukur pada suatu epoch untuk penentuan tinggi titik pantau epoch lainnya dapat menyebabkan adanya kesalahan sistematik pada hitungan perataan (Han, dkk., 2014). Oleh karena itu, perlu koreksi pada masing-masing parameter untuk menghindari kesalahan sistematik tersebut. Persamaan observasi dituliskan dengan persamaan 1 s.d 7:

$$
\begin{aligned}
& \Delta h_{i j, t k}=\left[h_{j, t j}+V_{j}\left(t_{k}-t_{j}\right)\right]-\left[h_{i, t i}+V_{i}\left(t_{k}-t_{i}\right)\right] \\
& l+v=A \Delta_{x}+f \\
& l_{x}+v_{x}=x_{0}+\Delta_{x} \\
& \Delta_{x}=\left(N+W_{x x}\right)^{-1}\left(t-W_{x x} f_{x}\right) \\
& N=A^{T} P A \\
& t=A^{T} P F \\
& F_{x}=x_{0}-l_{x}
\end{aligned}
$$

Dalam hal ini :

$$
\begin{array}{ll}
\Delta h_{i j, t k} & : \text { beda tinggi titik pantau } i \text { dan } j \text { hasil } \\
\text { ukuran } \text { epoch } t_{k}, & \\
h_{j, t j} \text { dan } h_{i, t i} & : \text { tinggi titik pantau } i \operatorname{dan} j, \\
V_{j} \text { dan } V_{i} & : \text { kecepatan pergeseran vertikal titik } \\
\text { pantau } i \text { dan } j, & \\
t_{j} \text { dan } t_{i} & : \text { epoch pendefinisian titik pantau } i \text { dan } j, \\
t_{k} & : \text { epoch pengukuran beda tinggi } \Delta h_{i j}, \\
l & : \text { nilai pengamatan dari tiga epoch yang } \\
\text { berbeda, } &
\end{array}
$$$$
l_{x}
$$

: nilai pengamatan untuk parameter $\mathrm{x}$,

$$
\begin{array}{ll}
v & : \text { nilai residu ukuran, } \\
v_{x} & : \text { nilai estimasi residu untuk parameter } \mathrm{x}, \\
\Delta_{x} & : \text { koreksi setiap parameter, } \\
x_{0} & : \text { nilai pendekatan parameter, } \\
A & : \text { matriks desain atau representasi }
\end{array}
$$
geometrik yang elemennya terdiri dari koefisien parameter, $F \quad:$ matriks sisa pengukuran hasil dari selisih estimasi pengamatan dengan nilai pengamatan, dan $P \quad$ : matriks bobot pengukuran.

Nilai $W_{x x}$ adalah matriks bobot untuk parameter $\mathrm{x}$ yang terdiri dari elemen $W_{1}, W_{2}$ dan $W_{3}$ yang merupakan matriks bobot tinggi dan kecepatan pergeseran vertikal tiap epoch. $W_{1}$ adalah bobot untuk tinggi dan kecepatan pergeseran vertikal titik ikat, sedangkan $W_{2}$ dan $W_{3}$ adalah bobot untuk tinggi dan kecepatan pergeseran vertikal setiap titik pantau. Matriks $W_{x x}$ dapat dituliskan sebagai persamaan 8.

$$
\begin{aligned}
W_{x x} & =\left[\begin{array}{ccc}
W_{1} & 0 & 0 \\
0 & W_{2} & 0 \\
0 & 0 & W_{3}
\end{array}\right] \\
W_{1} & =\sigma_{0}^{2} \sum \frac{-1}{h h} \\
& =\sigma_{0}^{2}\left[\begin{array}{cccc}
\sigma_{\overline{h_{1}}}^{2} & \sigma_{\overline{h_{1} h_{2}}} & \ldots & \sigma_{\overline{h_{1} h_{u}}} \\
\vdots & \sigma_{\overline{h_{2}}}^{2} & \ldots & \sigma_{\overline{h_{2} h_{u}}}^{-1} \\
\text { symm. } & & \ddots & \vdots \\
& \ldots & \ldots & \sigma_{\overline{h_{u}}}^{2}
\end{array}\right]
\end{aligned}
$$

Setelah koreksi ditentukan, maka estimasi parameter dapat dirumuskan persamaan 10:

$$
\hat{x}=x_{0}+\Delta_{x}
$$

dan matriks varian kovarian dihitung dengan persamaan 11:

$$
\sum_{\hat{x} \hat{x}}=\hat{\sigma}_{0}^{2}\left(N+W_{x x}\right)^{-1}
$$

Dalam hal ini $\hat{\sigma}_{0}$ adalah varian aposteriori yang dapat diestimasi dengan persamaan 12 :

$$
\begin{aligned}
& \hat{\sigma}_{0}=\sqrt{\frac{v^{T} P v+v_{x}^{T} W_{x x} v_{x}}{r}} \\
& r=n_{1}+n_{2}-u
\end{aligned}
$$

Dalam hal ini

$$
\begin{array}{ll}
r & : \text { derajat kebebasan, } \\
n_{1} & : \text { jumlah ukuran, } \\
n_{2} & \text { : parameter untuk model ukuran, } \\
u & : \text { parameter (termasuk titik acuan). }
\end{array}
$$

\section{B.Tahapan Penelitian}

Pelaksanaan penelitian ini terdiri atas tiga tahap yaitu tahap persiapan, tahap pengolahan data dan tahap analisis perbandingan pergeseran. Pada tahap pengolahan data terbagi menjadi dua langkah yakni pengolahan jaring pantau dengan menggunakan metode hitung perataan model parameter dan metode time-variant. Keseluruhan proses tersebut dijelaskan dengan diagram alir seperti pada Gambar 2.1. Adapun keterangan untuk masingmasing tahapan adalah sebagai berikut. 


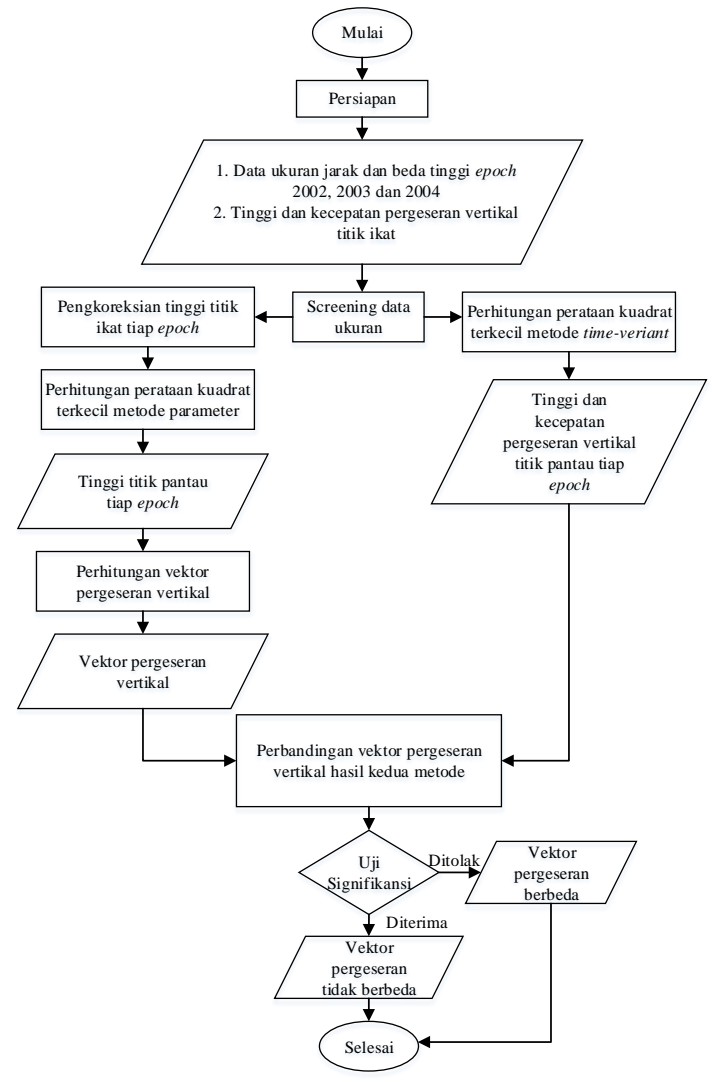

Gambar 2.1 Diagram alir penelitian

\section{Persiapan}

Penelitian ini diawali dengan tahap persiapan bahan serta alat penelitian. Bahan penelitian didapat dari hasil pengukuran sipat datar oleh Tim BKB tahun 2002, 2003 dan 2004, sedangkan tinggi dan kecepatan pergerakan vertikal titik ikat BORE dari pengamatan GPS oleh Lestari (2015). Proses screening data ukuran dalam penelitian ini dilakukan dengan tujuan menghindari munculnya data yang mengandung kesalahan kasar. Pengecekan kesalahan kasar dilakukan dengan cara mengamati besaran antar ukuran beda tinggi pulang-pergi dalam satu seksi. Jika perbedaan nilai ukuran sangat besar, maka data harus dibuang dan tidak diproses dalam proses perataan.

\section{Hitungan Kuadrat Terkecil Metode Parameter Epoch Terpisah}

Tahap ini meliputi langkah-langkah penentuan tinggi titik-titik pantau jaring sipat datar Candi Borobudur beserta ketelitiannya dan uji statistik data pengamatan. Kedua tahapan tersebut dilakukan terpisah untuk setiap epoch. Prinsip hitungan kuadrat terkecil metode parameter pada jaring sipat datar Candi Borobudur diawali dengan melakukan koreksi tinggi titik ikat pada setiap epoch.

Nilai tinggi titik BORE terkoreksi pada tahun 2002 adalah 288,8070 m, pada tahun 2003 adalah 288,8027 m dan pada tahun 2004 adalah 288,7982 m. Selanjutnya hitungan kuadrat terkecil metode parameter dilakukan dengan menyusun persamaan pengamatan beda tinggi dengan memperhatikan bentuk konfigurasi jaring sipat datar Candi Borobudur. Jumlah persamaan pengamatan sebanyak 73, yakni sebagai berikut:

$$
\begin{aligned}
& l_{1}+v_{1}=H_{I V}-H_{B O R E} \\
& l_{2}+v_{2}=H_{V}-H_{I V} \\
& \vdots \\
& \vdots \\
& l_{72}+v_{72}=H_{B D 5}-H_{S 5} \\
& l_{73}+v_{73}=H_{B 5}-H_{B D 5}
\end{aligned}
$$

Dari persamaan tersebut, kemudian dijabarkan hitungan matriks-matriks (A, X, V, F) dan estimasi tinggi titik dihitung dengan konsep hitungan perataan kuadrat terkecil metode parameter (Wolf, 1981) dengan bobot ukuran sesuai dengan pengolahan sebelumnya oleh Koesumakristi (2005). Hasil hitungan perataaan ini diuji dengan metode Pope's Tau $(\tau)$ (Kuang, 1996) dengan tingkat kepercayaan 95\%.

\section{Penentuan Vektor Pergerakan Vertikal}

Pada tahap ini terdiri dari dua langkah pokok yakni perhitungan vektor pergerakan vertikal antara dua epoch dan uji statistik terhadap kemungkinan terjadinya pergerakan vertikal pada dua epoch tersebut. Untuk setiap pasangan epoch 2002 dan 2003, serta 2003 dan 2004, dilakukan tahapan sebagai berikut:

1. Menghitung nilai vektor pergerakan vertikal $(d)$ setiap titik pantau.

2. Menghitung matriks varian kovarian pergerakan $\sum_{d d}$

3. Melakukan uji signifikansi pergerakan, dalam penelitian ini menggunakan prinsip uji signifikansi beda dua parameter. Pada penelitian ini digunakan tingkat kepercayaan 95\%, menggunakan persamaan 19 (Mikhail \& Gracie, 1981):

$$
\tau_{x_{i}}=\left|\frac{x_{i}^{(1)}-x_{i}^{(2)}}{\sqrt{\left(\sigma_{x_{i}}^{(1)}\right)^{2}+\left(\sigma_{x_{i}}^{(2)}\right)^{2}}}\right|
$$

Dalam hal ini:

$$
\begin{array}{ll}
x_{i}^{(1)} \text { dan } x_{i}^{(2)} & \text { : parameter satu dan parameter dua, } \\
\sigma_{x_{i}}^{(1)} \text { dan } \sigma_{x_{i}}^{(2)} & \text { : simpangan baku parameter satu dan } \\
& \text { parameter dua. }
\end{array}
$$

\section{Hitungan Perataan Metode Time-Variant}

Tahapan ini terdiri dari langkah penentuan tinggi titik pantau pada epoch pengamatan tertentu serta kecepatan pergerakan vertikal titik pantau, dan ketelitian tinggi serta ketelitian kecepatan pergerakan vertikal titik pantau. Dalam proses perhitungan metode ini, kecepatan pergerakan vetikal setiap titik pantau menjadi parameter yang ditentukan nilai estimasinya bersamaan dengan penentuan nilai estimasi tinggi titik pantau. Epoch pengukuran beda tinggi dan epoch titik pantau yang menjadi parameter memiliki kemungkinan berbeda sesuai dengan model matematis yang digunakan. Berikut langkahlangkah yang dilakukan untuk interval antara epoch tahun 2002 dan 2003 serta 2003 dan 2004.

1. Menentukan derajat kebebasan (r). Pada metode ini terdapat 73 ukuran beda tinggi $\left(n_{1}\right)$ pada jaring pantau, 52 buah titik pantau yang akan dihitung estimasi tinggi serta kecepatan pergerakan vertikal (vertical velocities) masing-masing titik pantau sebagai parameter sehingga jumlah parameter untuk persamaan ukuran $\left(n_{2}\right)$ adalah 104, dan jumlah 
parameter termasuk titik ikat serta kecepatan pergerakan vertikal titik ikat $(u)$ adalah 106 sehingga $r=n_{1}+n_{2}-u=71$.

2. Menyusun persamaan pengamatan beda tinggi dengan memperhatikan bentuk konfigurasi jaring sipat datardengan jumlah persamaan pengamatan sebanyak 73 yakni sebagai berikut:

$$
\begin{aligned}
& \Delta h_{B O R E, I V}^{(2003)}=\left[\overline{h_{I V}^{(2002)}}+V_{I V}(2003-2002)\right. \\
& \left.-\left[\overline{h_{B O R E}^{(2002)}}+V_{B O R E}(2003-2002)\right]\right] \\
& \Delta h_{B D 5, B 5}^{(2003)}=\left[\overline{h_{B 5}^{(2002)}}+V_{B 5}(2003-2002)\right] \\
& -\left[\overline{h_{B D 5}^{(2002)}}+V_{B D 5}(2003-2002)\right](16)
\end{aligned}
$$

3. Menentukan tinggi pendekatan dan kecepatan pergerakan vertikal pendekatan setiap titik pantau sesuai interval epoch pengamatan. Penelitian ini menggunakan tinggi pendekatan hasil hitungan perataan metode parameter untuk epoch tahun 2002 dan tinggi pendekatan hasil hitungan perataan metode time-variant untuk epoch tahun 2003. Pendekatan kecepatan pergerakan vertikal titik pantau pada penelitian ini sebesar $0 \mathrm{~m}$ /tahun karena diasumsikan belum terjadi pergerakan vertikal pada titik pantau.

4. Menentukan matriks estimasi pengukuran tinggi dan kecepatan pergerakan vertikal titik pantau termasuk pada titik ikat.

5. Menyusun matriks A yang merupakan turunan persamaan pengamatan terhadap parameter. Parameter dalam metode hitung kuadrat time-variant berisi tinggi dan kecepatan pergerakan titik pantau dan termasuk titik ikat

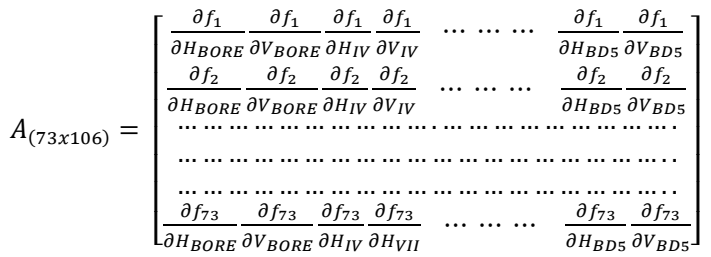

6. Membentuk matriks bobot pengamatan (P) dengan dimensi $73 \times 73$.

7. Menyusun vektor sisa (F) dengan dimensi 73x1 yang disusun berdasarkan persamaan pengamatan beda tinggi sesuai epoch yang digunakan pada persamaan.

8. Menyusun matriks $F_{x}$ yang merupakan matriks sisa parameter, yaitu elemennya berisi selisih nilai pendekatan parameter dengan nilai estimasi pengamatan.

$$
F_{x_{(106 \times 1)}}=\left[\begin{array}{c}
H^{o}{ }_{B O R E}-H_{B O R E} \\
V^{o}{ }_{B O R E}-V_{B O R E} \\
H^{o}{ }_{I V}-H_{I V} \\
V^{o}{ }_{I V}-V_{I V} \\
\vdots \\
H^{o}{ }_{B D 5}-H_{B D 5} \\
V^{o}{ }_{B D 5}-V_{B D 5}
\end{array}\right]
$$

9. Menyusun matriks bobot untuk parameter $\left(W_{x x}\right)$, elemen matriks bobot pada penelitian ini berisi satu per varian ukuran dan varian tinggi titik pantau pendekatan pada elemen diagonal utamanya. Varian apriori $\left(\sigma_{o}^{2}\right)$ yang digunakan pada bobot parameter bernilai satu untuk mempermudah proses perhitungan. Matriks $W_{x x}$ berisi simpangan baku tinggi dan kecepatan pergerakan titik ikat dan titik pantau.

$$
W_{x x}=\sigma_{0}^{2} \sum \frac{-1}{h h}=\sigma_{0}^{2}\left[\begin{array}{cccc}
\sigma_{\overline{h_{1}}}^{2} & \sigma_{\overline{h_{1} h_{2}}} & \cdots & \sigma_{\overline{h_{1}} h_{u}} \\
\vdots & \sigma_{\overline{h_{2}}}^{2} & \ldots & \sigma_{\overline{h_{2}} h_{u}} \\
& & \ddots & \vdots \\
\text { symm. } & \ldots & \ldots & \sigma_{\overline{h_{u}}}^{2}
\end{array}\right]^{-1}
$$

10. Menghitung nilai koreksi parameter $\Delta_{x}$, menghitung nilai estimasi parameter $\hat{x}$, menyusun matriks residu ukuran $v$ dan matriks residu parameter $v_{x}$, menghitung varian aposteriori $\hat{\sigma}_{0}^{2}$, menghitung varian kovarian parameter $\sum_{\hat{x} \hat{x}}$ menggunakan persamaan 10 s.d 13.

11. Melakukan uji global untuk mengecek kesesuaian model matematis yang digunakan pada perataan timevariant karena uji statistik untuk mendeteksi kesalahan tak acak pada data pengamatan telah dilakukan pada tahap hitungan perataan metode parameter sebelumnya.

12. Melakukan uji signifikansi pergerakan dalam penelitian ini menggunakan prinsip uji signifikansi beda dua parameter dengan tingkat kepercayaan 95\%.

\section{Uji Signifikansi Beda Pergerakan}

Perbandingan hasil vektor pergerakan dari hitungan perataan metode parameter dengan koreksi titik ikat dan metode time-variant dilakukan menggunakan uji signifikansi beda dua parameter. Proses pengujian memerlukan data vektor pergerakan tiap titik pantau hasil kedua metode serta simpangan bakunya. Pengujian dilakukan pada interval epoch 2002 dan 2003 serta epoch 2003 dan 2004. Pengujian dilakukan untuk tingkat kepercayaan $95 \%$.

\section{Hasil dan Pembahasan}

\subsection{Hasil Hitungan Kuadrat Terkecil Metode Parameter}

Hasil akhir dari hitungan kuadrat terkecil metode parameter dengan koreksi tinggi titik ikat pada jaring sipat datar adalah tinggi titik pantau beserta simpangan bakunya. Terdapat 52 tinggi titik pantau beserta simpangan bakunya untuk tiap epoch pengamatan 2002, 2003 dan 2004. Nilai rerata simpangan baku tinggi titik pantau pada epoch 2002 sebesar 0,5 mm, pada epoch 2003 sebesar 1,0 mm dan pada epoch 2004 sebesar 0,5 mm. Berdasarkan hasil hitungan perataan, nilai varian aposteriori jaring epoch 2003 sebesar 0,510 sedangkan pada epoch 2002 sebesar 0,116 dan pada epoch 2004 sebesar 0,147. Nilai residu parameter pada jaring epoch 2003 lebih besar jika dibandingkan nilai residu parameter jaring pada epoch 2002 dan 2004. Hal tersebut menunjukkan ketelitian ukuran jaring epoch 2003 lebih rendah dari pada pengukuran jaring epoch 2002 dan epoch 2004, namun berdasarkan hasil uji dengan Pope's Tau tidak terdapat blunder pada pengukuran. 


\subsection{Hasil Analisis Pergerakan Vertikal}

Berdasarkan hasil hitungan vektor pergerakan vertikal dapat dilakukan analisis bahwa secara umum pada interval epoch pengamatan tahun 2002 dan 2003 terjadi kenaikan secara menyeluruh di semua titik pantau candi karena nilai vektor bertanda positif yang berarti arah pergerakan ke atas. Nilai pergerakan pada interval epoch tahun 2002 dan tahun 2003 berkisar 6,343 $\mathrm{mm}$ hingga 27,770 $\mathrm{mm}$ dengan rerata $8,006 \mathrm{~mm}$. Vektor pergerakan terkecil terjadi pada titik VI sedangkan pergerakan terbesar terjadi pada titik IV. Simpangan baku vektor pergerakan berikisar $0,786 \mathrm{~mm}$ hingga $1,228 \mathrm{~mm}$ dengan rerata $1,106 \mathrm{~mm}$. Simpangan baku terkecil dimiliki oleh titik IV sedangkan simpangan baku terbesar oleh titik VIII.

Berdasarkan analisis tersebut, titik IV mengalami pergerakan vertikal terbesar dan memiliki perbedaan pergerakan yang cukup jauh dibandingkan pergerakan titik pantau lainnya. Hal tersebut diakibatkan oleh akuisisi data beda tinggi antara titik BORE dengan titik IV yang hanya dilakukan sekali pengukuran pada epoch tahun 2002. Berbeda dengan akuisisi data beda tinggi lainnya yang diamat lebih dari satu kali.

Hasil pergerakan vertikal pada interval epoch pengamatan tahun 2003 dan tahun 2004 menunjukkan penurunan di semua titik pantau candi karena nilai vektor pergerakan bertanda negatif yang berarti arah pergerakan ke bawah. Nilai pergerakan pada interval epoch tahun 2003 dan tahun 2004 berkisar -2,821 mm hingga -6,293 mm dengan rerata $-4,229 \mathrm{~mm}$. Vektor pergerakan terkecil terjadi pada titik VII sedangkan pergerakan terbesar terjadi pada titik VI. Simpangan baku vektor pergerakan berkisar antara $0,805 \mathrm{~mm}$ hingga $1,258 \mathrm{~mm}$ dengan rerata 1,133 mm. Simpangan baku terkecil dimiliki oleh titik IV sedangkan simpangan baku pergerakan terbesar oleh titik VIII.

Untuk memastikan bahwa vektor pergerakan titik pantau merupakan pergerakan titik sesungguhnya dan signifikan maka perlu dilakukan analisis pergerakan berupa uji signifikansi pergerakan. Hasil uji signifikansi pergerakan titik pantau pada interval epoch pengamatan tahun 2002 dan tahun 2003 menunjukkan bahwa nilai $\tau_{i}$ berkisar dari 5,344 sampai 35,328 dengan rerata 7,405. Nilai $\tau_{i}$ setiap titik pantau pada interval pengamatan tahun 2002 dan 2003 melebihi nilai batas $\tau_{0.025 ; 21}$ yaitu sebesar 2,080 sehingga hipotesis nol pada uji ini ditolak, yang berarti semua titik pantau mengalami pergerakan secara signifikan. Pada interval epoch pengamatan tahun 2003 dan 2004 menunjukkan bahwa hipotesis nol pada uji signifikansi pergerakan vertikal juga ditolak di setiap titik pantau. Nilai $\tau_{i}$ berkisar dari 2,392 yang terletak di titik VII sampai 7,022 yang terletak pada titik IV dengan rerata 3,752 .

\subsection{Hasil Hitungan Kuadrat Terkecil Metode Time-Variant}

Pada hasil hitungan perataan metode time-variant untuk interval epoch tahun 2002 dan 2003 terjadi pergerakan vertikal ke arah atas (kenaikan) pada setiap titik pantau. Pergesaran vertikal titik pantau rerata sebesar 8,006 $\mathrm{mm}$ dengan pergerakan vertikal terkecil terjadi pada titik VI dengan nilai $6,343 \mathrm{~mm}$, sedangkan pergerakan terbesar terjadi pada titik IV dengan nilai pergerakan 27,770 $\mathrm{mm}$. Simpangan baku pergerakan $\left(\sigma_{V}\right)$ terbesar terletak pada titik VIII dengan nilai 1,071 $\mathrm{mm}$ sedangkan simpangan baku terkecil pada titik IV dengan nilai 0,953 $\mathrm{mm}$. Rerata simpangan baku pergerakan pada interval epoch tahun 2002 dan 2003 sebesar 1,036 mm.

Hasil hitungan perataan jaring pengamatan antara epoch 2003 dan 2004 menunjukkan penurunan pada semua titik pantau dengan rerata pergerakan $-4,229 \mathrm{~mm}$. Penurunan terkecil pada titik VII dengan nilai pergerakan 2,821 $\mathrm{mm}$, sedangkan penurunan terbesar terletak pada titik VI dengan nilai pergerakan -6,293 $\mathrm{mm}$. Hasil hitungan perataan time-variant menunjukkan simpangan baku pergerakan titik pantau berkisar antara $0,555 \mathrm{~mm}$ pada titik IV hingga $0,616 \mathrm{~mm}$ pada titik VIII dengan rerata ketelitian pergerakan sebesar 0,597 $\mathrm{mm}$.

Uji signifikansi pergerakan vertikal dilakukan untuk mendeteksi bahwa vektor pergerakan hasil hitungan peratan metode time-variant merupakan nilai pergerakan yang signifikan. Penolakan hipotesis nol pada uji ini berarti terjadi pergerakan yang signifikan secara statistik di setiap titik pantau. Hasil tersebut sama dengan hasil uji signifikansi pergerakan vertikal dari metode parameter dengan koreksi tinggi titik ikat.

\subsection{Hasil Perbedaan Analisis Pergerakan Vertikal} Menggunakan Metode Parameter dan Metode Time Variant

Uji signifikansi dilakukan untuk mengetahui bahwa perbedaan pergerakan hasil hitungan perataan metode parameter dan metode time-variant signifikan secara statistik. Hasil uji signifikansi perbedaan pergerakan titik pantau pada interval epoch pengamatan tahun 2002 dan 2003 serta 2003 dan 2004 menunjukkan bahwa hipotesis nol diterima. Penerimaan tersebut menunjukkan vektor pergerakan semua titik pantau hasil hitungan perataan metode parameter dengan koreksi titik ikat sama secara statistik dengan hasil metode time-variant. Kedua hasil analisis pergerakan vertikal tersebut memiliki nilai vektor pergerakan yang hampir sama. Adapun selisih kedua nilai vektor pergerakan tersebut dalam fraksi nano milimeter. Perbandingan pergerakan dan simpangan baku pergerakan disajikan dalam bentuk diagram perbandingan. Perbandingan untuk interval 2002 dan 2003 dijelaskan pada Gambar 3.1.

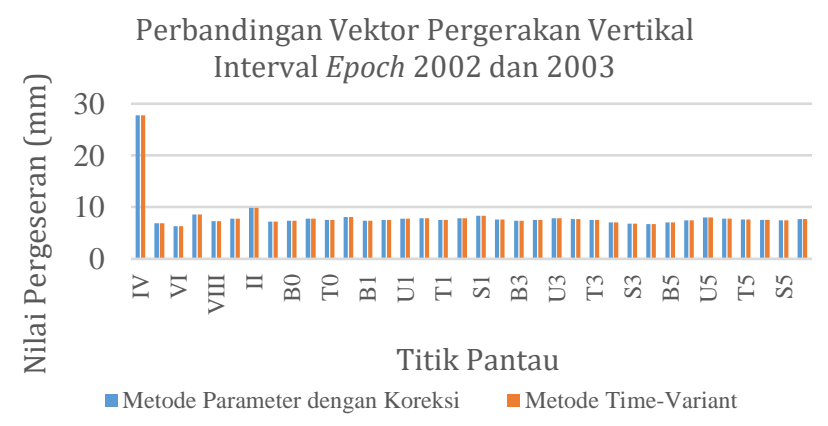

Gambar 3.1 Perbandingan vektor pergeseran vertikal interval epoch 2002 dan 2003. 
Grafik pada Gambar 3.1 menjelaskan bahwa nilai vektor pergeseran hasil hitungan perataan metode parameter dengan koreksi tinggi titik ikat pada tiap epoch dan nilai vektor pergeseran hasil hitungan metode timevariant untuk interval 2002 dan 2003 adalah sama. Selisih keduanya dalam fraksi nano milimeter sehingga tidak dapat terlihat jelas karena sangat kecil. Selain visualisasi perbandingan dengan grafik, untuk meyakinkan ada tidaknya perbedaan hasil dilakukan uji signifikansi perbedaan pergeseran hasil kedua metode tersebut. Uji signifikansi pada tingkat kepercayaan $95 \%$ diterima yang berarti hasil pergerakan vertikal kedua metode yang diuji adalah sama. Pada titik IV terjadi pergeseran yang paling besar secara signifikan dibanding titik pantau lain yakni sebesar 27,770 mm. Nilai pergeseran titik IV tersebut bernilai sama dari hasil analisis hitung perataan terkecil metode parameter maupun metode time-variant. Besarnya nilai pergeseran vertikal titik IV diduga dikarenakan pengamatan beda tinggi titik BORE dan titik IV pada epoch 2002 yang hanya diukur satu kali. Hal tersebut menyebabkan tinggi titik IV pada epoch 2002 memiliki ketelitian presisi tinggi namun tidak akurat.

Pada hitung perataan kuadrat terkecil metode parameter dengan koreksi tinggi titik ikat, tidak memperhitungkan ketelitian titik ikat dan ketelitian kecepatan pergeseran titik ikat tersebut, karena titik ikat yang sudah dikoreksi tiap epoch dianggap nilai yang tetap. Hal tersebut menyebabkan titik IV sebagai titik yang mengikat mendapatkan koreksi langsung dari titik ikat dan memiliki simpangan baku tinggi titik terkecil dibanding titik lain. Berbeda dengan hitung perataan kuadrat terkecil metode time-variant yang memperhitungkan ketelitian tinggi dan ketelitian kecepatan pergeseran titik ikat karena titik ikat dianggap masih memiliki kesalahan dan perlu dikoreksi. Selanjutnya untuk interval 2003 dan 2004 diilustrasikan pada Gambar 3.2.

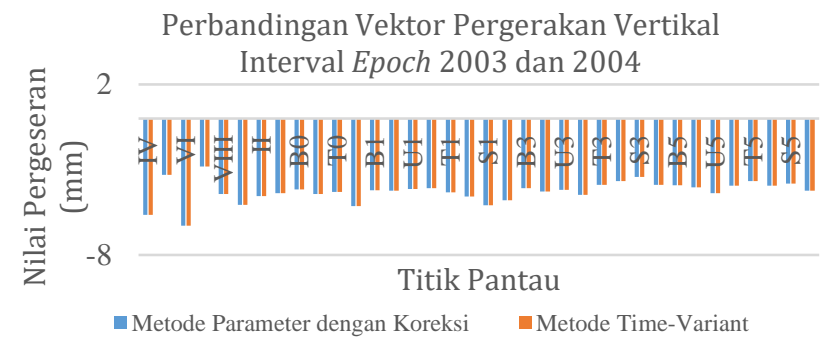

Gambar 3.2 Perbandingan vektor pergerakan vertikal interval epoch 2003 dan 2004

Berbeda dengan interval pengamatan sebelumnya, pola pergerakan antara tahun 2003 dan 2004 seperti yang dijelaskan pada Gambar 3.2 adalah pola penurunan. Nilai pergerakan yang dihasilkan dari hitungan menggunakan metode parameter dengan koreksi titik ikat dengan hasil hitungan metode time variant juga menunjukkan hasil yang sama, dengan magnitude pergerakan yang hampir merata untuk semua titik pantau. Hasil uji statistik perbedaan dua parameter, pada tingkat kepercayaan $95 \%$ menyatakan bahwa analisis pergerakan dengan kedua metode tersebut tidak berbeda secara signifikan, namun metode time variant memberikan nilai rerata simpangan baku yang 1,5 kali lebih kecil dari metode parameter dengan koreksi titik ikat.

Merujuk pada hasil penelitian sebelumnya (Koesoemakristi, 2005), besar dan arah pergerakan vertikal yang dihasilkan berbeda secara signifikan. Perbedaan hasil analisis dengan dan tanpa pemberian koreksi tinggi pada titik ikat dapat dicontohkan pada hasil analisis metode time variant untuk interval epoch 2003 dan 2004 seperti Gambar 3.3.

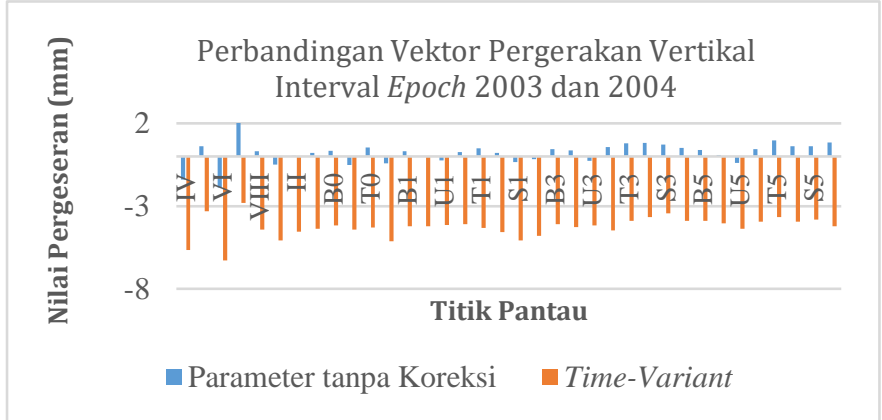

Gambar 3.3 Perbedaan vektor pergerakan vertikal antara metode parameter tanpa koreksi tinggi titik ikat dengan metode time variant (epoch 2003 dan 2004)

Grafik di atas menjelaskan bahwa besar dan pola analisis pergerakan vertikal yang dihasilkan berbeda signifikan. Analisis dengan metode parameter dengan mengasumsikan titik ikat (BORE) fix untuk epoch 2003 dan 2004 memberikan nilai pergerakan yang relatif lebih kecil dengan arah pergerakan sebagian titik ke atas. Sementara analisis dengan time variant memberikan nilai pergerakan yang lebih besar dengan arah yang berlawanan. Perbedaan tersebut akibat adanya koreksi tinggi titik ikat yang diberikan pada metode time variant.

\subsection{Kelebihan dan Kelemahan Hitung Kuadrat Terkecil Parameter dan Time-Variant}

Berdasarkan pada proses dan hasil dari penelitian ini, kedua metode perhitungan yang digunakan memiliki kelebihan dan kelemahan masing-masing. Kelebihan dan kelemahan hitung kuadrat terkecil metode parameter dengan koreksi titik ikat jika dibandingkan dengan metode time-variant antara lain:

1) Pada proses perhitungannya tidak memerlukan nilai pendekatan parameter sehingga tidak perlu melakukan perhitungan pendekatan jika memang tidak tersedia nilai pendekatan parameter.

2) Perhitungan vektor pergeseran vertikal pada interval epoch lebih dari satu tahun lebih mudah dilakukan.

3) Proses perhitungan lebih lama karena terbagi menjadi dua tahapan perhitungan terpisah antara penentuan tinggi titik pantau tiap epoch dan perhitungan vektor pergeseran vertikal.

4) Nilai simpangan baku pergeseran titik pantau lebih besar karena koreksi tinggi titik ikat tiap epoch tidak memperhitungkan simpangan baku kecepatan pergeseran titik ikat.

Kelebihan dan kelemahan hitung kuadrat terkecil metode time-variant jika dibandingkan dengan metode parameter dengan koreksi titik ikat antara lain: 
1) Proses perhitungan kecepatan pergeseran vertikal lebih cepat karena langsung terdefinisikan dari hasil hitungan perataan.

2) Proses pengoreksian tinggi titik ikat dilakukan langsung di dalam proses hitungan perataan sehingga memperhitungkan simpangan baku kecepatan pergeseran titik ikat.

3) Menghasilkan nilai simpangan baku pergeseran vertikal yang lebih kecil.

4) Memerlukan nilai pendekatan parameter dalam proses perhitungannya.

\section{Kesimpulan}

Pemantauan stabilitas titik kontrol jarring deformasi perlu dilakukan agar analisis yang dihasilkan menjadi lebih tepat. Penelitian ini membuktikan bahwa pemberian koreksi tinggi titik ikat pada analisis pergerakan vertikal jaring pemantau Candi Borobudur, baik menggunakan metode hitung kuadrat terkecil dengan model parameter maupun dengan metode time variant memberikan hasil yang relatif sama.

Pada interval epoch 2002 dan 2003 terjadi pergerakan vertikal ke atas di semua titik pantau dengan rerata pergerakan sebesar 8,006 mm. Simpangan baku pergerakan vertikal rerata untuk metode parameter dengan koreksi tinggi titik ikat sebesar 1,106 mm, sedangkan metode time variant memberikan nilai simpangan baku pergeseran rerata sebesar 1,036 mm. Pada interval epoch tahun 2003 dan 2004 menunjukkan pergeseran vertikal ke arah bawah (penurunan) di semua titik pantau. Vektor pergeseran vertikal rerata sebesar 4,229 mm dan simpangan baku pergerakan vertikal rerata sebesar 1,133 mm untuk metode parameter dan 0,597 mm untuk metode time variant. Hasil analisis tersebut berbeda signifikan dengan analisis pergerakan vertikal hasil hitung perataan kuadrat terkecil metode parameter tanpa koreksi tinggi titik ikat.

Nilai simpangan baku pergerakan vertikal hasil hitung perataan kuadrat terkecil metode time-variant lebih kecil dibandingkan simpangan baku pergeseran hasil hitung perataan kuadrat terkecil metode parameter dengan koreksi tinggi titik ikat. Selain itu, proses hitungan tinggi titik dan vektor kecepatan pergeseran dapat dilakukan sekaligus dalam satu proses hitungan, sehingga pada kasus titik ikat yang mengalami perubahan posisi, analisis menggunakan metode time variant bias dijadikan solusi.

\section{Pernyataan Konflik Kepentingan}

Penulis menyatakan tidak ada konflik kepentingan dalam artikel ini (The authors declare no competing interest).

\section{Referensi}

Anggraeni, A.R, 2001, Deformasi Arah Vertikal Akibat Konsolidasi Tanah Dasar Fondasi Candi Borobudur, Skripsi, Jurusan Teknik Sipil, Fakultas Teknik, Universitas Gadjah Mada, Yogyakarta, Indonesia
Basuki, S., 2006, Ilmu Ukur Tanah, Cetakan ke-1, Gadjah Mada Press, Yogyakarta, Indonesia.

Caspary, W.F, 1987, Concepts of Network and Deformation Analysis, Monograph 11, School of Surveying the University of New South Wales, Australia.

Han, J.Y., Hwang, C., Chou, J.Y., dan Hung, W.C., 2014, “TimeVariant Adjustment for a Level Network", Journal of Surveying Engineering, 140, 04014004-104014004-7.

Kuang, S., 1996, Gedetic Network Analysis and optimal Design: Concept and Applications, Ann Arbor Press Inc, Michigan.

Koesumakristi, M.Y., 2005, "Analisis Deformasi Vertikal Multi Epok Candi Borobudur", Skripsi, Jurusan Teknik Geodesi Fakultas Teknik UGM, Yogyakarta.

Lestari, D., 2015, "Analisis Stabilitas Candi Borobudur Berdasar Integrasi Data Pengamatan GPS dan Terestris Jaring Pemantau Deformasi Candi", Disertasi, Jurusan Teknik Geodesi Fakultas Teknik UGM, Yogyakarta.

Mikhail, E.M. dan Gracie, G., 1981, Analysis and Adjustment of Survey Measurements, Van Nostrand Reinhold Company Inc, New York.

Siswoyo, B., Subagyo, R., dan Chozin, M., 2002, Studi Deformasi Arah Vertikal Candi Borobudur dengan Sipat Datar Teliti, Balai Studi dan Konservasi Borobudur, Borobudur, Magelang, Jawa Tengah, Indonesia.

Siswoyo, B., Subagyo, R., dan Chozin, M., 2003, Studi Deformasi Arah Vertikal Candi Borobudur dengan Sipat Datar Teliti, Balai Studi dan Konservasi Borobudur, Borobudur, Magelang, Jawa Tengah, Indonesia

Siswoyo, B., Chozin, M., dan Santoso, A.C., 2004, Studi Deformasi Arah Vertikal Candi Borobudur dengan Sipat Datar Teliti, Balai Studi dan Konservasi Borobudur, Borobudur, Magelang, Jawa Tengah, Indonesia.

Wangsadinata, W. dan Djayaputra, A., 1982, Final Review of The Long Term Stability and Performance of Candi Borobudur, Reports and Documents of The Consultative Committee for The Safeguarding of Borobudur, Pelita Borobudur Seri CC No.11, Proyek Pelita Pemugaran Candi Borobudur, Departemen Pendidikan dan Kebudayaan RI, Indonesia

Widjajanti, N., 2001, Diktat Deformasi Dasar, Jurusan Teknik Geodesi Fakultas Teknik UGM, Yogyakarta.

Wolf, P.R, 1981, Adjustment Computation (PLSS), $2^{\text {nd }}$ Edition, Departemen Geodesi Fakultas Teknik Sipil dan Perencanaan ITB, Bandung.

Yulaikhah dan Widjajanti, N., 2004, Analisis Pergeseran Horisontal Bendungan Panglima Besar Soedirman, Jurusan Teknik Geodesi Fakultas Teknik, Universitas Gadjah Mada, Yogyakarta. 